\title{
Mechercharmycins A and B, Cytotoxic Substances from Marine-derived Thermoactinomyces sp. YM3-251
}

\author{
Kaneo Kanoh, Yoshihide Matsuo, Kyoko Adachi, Hiroshi Imagawa, Mugio Nishizawa, \\ Yoshikazu Shizuri
}

Received: February 3, 2005 / Accepted: March 17, 2005

(C) Japan Antibiotics Research Association

\begin{abstract}
A new cytotoxic substance named mechercharmycin A was isolated from marine-derived Thermoactinomyces sp. YM3-251. The structure of mechercharmycin A was determined by an X-ray crystallographic analysis to be cyclic peptide-like and bearing four oxazoles and a thiazole. Mechercharmycin $\mathrm{B}$, a linear congener of mechercharmycin $\mathrm{A}$, was also isolated from the same bacterium. Mechercharmycin A exhibited relatively strong antitumor activity, whereas mechercharmycin B exhibited almost no such activity.
\end{abstract}

Keywords cytotoxic, marine-derived Thermoactinomyces, cyclic peptide

Table 1 Physico-chemical properties of $\mathbf{1}$ and $\mathbf{2}$
Marine microorganisms have been recognized as a promising source for the development of new pharmaceuticals [1]. In the course of screening for antitumor substances from marine-derived microorganisms, we found the cyclic peptide-like compound bearing four oxazoles and a thiazol, mechercharmycin A (1) [2], and its linear congener, mechercharmycin B (2). The strain producing 1 and 2, Thermoactinomyces sp. YM3-251 [3], was isolated from sea mud collected at Mecherchar in the Republic of Palau (North Pacific Ocean). The producing strain was cultured in a $\mathrm{B} 2$ medium [4] at $30^{\circ} \mathrm{C}$ with rotary shaking at $100 \mathrm{rpm}$ for 7 days. The cultured broth was centrifuged. The resulting precipitate was extracted by chloroform/methanol $(9: 1)$, and the supernatant was extracted by ethyl acetate. Both these extracts were

\begin{tabular}{lll}
\hline & \multicolumn{1}{c}{$\mathbf{1}$} & \multicolumn{1}{c}{$\mathbf{2}$} \\
\hline $\begin{array}{l}\text { Appearance } \\
\text { Molecular formula }\end{array}$ & White powder & White powder \\
Molecular weight & $\mathrm{C}_{35} \mathrm{H}_{32} \mathrm{~N}_{8} \mathrm{O}_{7} \mathrm{~S}$ & $\mathrm{C}_{35} \mathrm{H}_{36} \mathrm{~N}_{8} \mathrm{O}_{10}$ \\
HRFAB-MS $(\mathrm{m} / z)$ & 708 & 728 \\
$\quad$ & & \\
$\quad$ Found & $709.2104(\mathrm{M}+\mathrm{H})^{+}$ & $729.2612(\mathrm{M}+\mathrm{H})^{+}$ \\
$\quad$ Calcd. & 709.2193 & 729.2633 \\
{$[\alpha]_{\mathrm{D}}^{25}$} & $+110^{\circ}(\mathrm{c} 0.038, \mathrm{DMSO})$ & $+56^{\circ}(\mathrm{c} 0.056, \mathrm{DMSO})$ \\
$\mathrm{UV} \lambda_{\max } \mathrm{nm}(\log \varepsilon)$ in $\mathrm{MeOH}$ & $223(4.71), 260(4.73), 300(\mathrm{sh})$ & $220(4.65), 261(4.62), 310(\mathrm{sh})$ \\
IR $v_{\max }(\mathrm{KBr}) \mathrm{cm}^{-1}$ & $3400,2962,2925,1655,1543,1509$ & $3400,2964,2927,1743,1655,1543,1509$ \\
\hline
\end{tabular}

K. Kanoh (Corresponding author), Y. Matsuo, K. Adachi, Y. Shizuri: Marine Biotechnology Institute Co. Ltd., 3-75-1 Heita, Kamaishi, Iwate 026-0001, Japan, E-mail: kaneo.kanoh@mbio.jp
H. Imagawa, M. Nishizawa: Faculty of Pharmaceutical Sciences, Tokushima Bunri University, Yamashiro-cho, Tokushima 7708514, Japan 
combined, and the mixture was chromatographed on a silica gel column by step-wise elution with chloroform/methanol (1 6\% methanol). Antitumor activity was observed in the $4 \%$ methanol-chloroform fraction, and this fraction was further separated by HPLC.
Finally, $7 \mathrm{mg}$ of $\mathbf{1}$ was obtained from a 200-liter culture, and $3 \mathrm{mg}$ of 2 was also obtained from the same fraction. The physico-chemical properties of $\mathbf{1}$ and $\mathbf{2}$ are summarized in Table 1, and the NMR data are presented in Table 2 .

Table $2{ }^{1} \mathrm{H}$ and ${ }^{13} \mathrm{C}$ NMR data of $\mathbf{1}$ and 2 in DMSO- $d_{6}\left(750 \mathrm{MHz}\right.$ for ${ }^{1} \mathrm{H}$ and $125 \mathrm{MHz}$ for $\left.{ }^{13} \mathrm{C}\right)$

\begin{tabular}{|c|c|c|c|c|}
\hline \multirow{2}{*}{ Position } & \multicolumn{2}{|c|}{ Mechercharmycin A (1) } & \multicolumn{2}{|c|}{ Mechercharmycin B (2) } \\
\hline & ${ }^{13} \mathrm{C}$ & ${ }^{1} \mathrm{H}$ mult., $J(\mathrm{~Hz})$ & ${ }^{13} \mathrm{C}$ & ${ }^{1} \mathrm{H}$ mult., $J(\mathrm{~Hz})$ \\
\hline 1 & 157.14 & & 161.22 & \\
\hline 2 & 135.50 & & 137.12 & \\
\hline 3 & 139.32 & $9.06 \mathrm{~s}$ & 141.95 & $8.65 \mathrm{~s}$ \\
\hline 4 & 154.63 & & 153.79 & \\
\hline 5 & $129.53^{*}$ & & 129.83 & \\
\hline 6 & 140.27 & $8.95 \mathrm{~s}$ & 140.70 & $8.85 \mathrm{~s}$ \\
\hline 7 & 158.78 & & 158.86 & \\
\hline 8 & 128.54 & & 128.79 & \\
\hline 9 & 109.31 & $5.79 \mathrm{~s}, 5.92 \mathrm{~s}$ & 108.22 & $5.71 \mathrm{~s}, 5.94 \mathrm{~s}$ \\
\hline 10 & 170.71 & & 170.89 & \\
\hline 11 & 58.14 & $4.78 t, 8.6$ & 58.12 & $4.48 \mathrm{dd}, 8.1,7.1$ \\
\hline 12 & 32.05 & $2.05 \mathrm{~m}$ & 30.32 & $2.13 \mathrm{~m}$ \\
\hline 13 & 19.13 & $0.95 d, 6.8$ & 18.00 & $0.94 d, 6.8$ \\
\hline 14 & 18.55 & $1.00 \mathrm{~d}, 6.8$ & 19.18 & $0.96 \mathrm{~d}, 6.8$ \\
\hline 15 & 170.08 & & 170.76 & \\
\hline 16 & 56.92 & $4.65 \mathrm{dd}, 6.6,3.9$ & 55.53 & $4.75 \mathrm{dd}, 9.1,5.3$ \\
\hline 17 & 38.66 & $2.07 \mathrm{~m}$ & 37.90 & $1.96 \mathrm{~m}$ \\
\hline 18 & 14.35 & $0.89 d, 6.8$ & 14.29 & $0.90 \mathrm{~d}, 6.8$ \\
\hline 19 & 26.07 & 1.13 m, 1.64 m & 25.99 & $1.18 \mathrm{~m}, 1.48 \mathrm{~m}$ \\
\hline 20 & 12.01 & $0.93 t, 7.5$ & 11.46 & $0.93 t, 7.5$ \\
\hline 21 & 159.90 & & 159.67 & \\
\hline 22 & 130.59 & & 129.70 & \\
\hline 23 & 150.35 & & 151.25 & \\
\hline 24 & 126.41 & & 126.16 & \\
\hline 25 & 127.15 & $8.31 \mathrm{~d}, 7.5$ & 127.76 & $8.25 d, 7.5$ \\
\hline 26 & 128.48 & $7.55 t, 7.5$ & 128.30 & $7.51 \mathrm{~m}$ \\
\hline 27 & 129.90 & $7.50 t, 7.5$ & 130.07 & $7.51 \mathrm{~m}$ \\
\hline 28 & 128.48 & $7.55 t, 7.5$ & 128.30 & $7.51 \mathrm{~m}$ \\
\hline 29 & 127.15 & $8.31 \mathrm{~d}, 7.5$ & 127.76 & $8.25 d, 7.5$ \\
\hline 30 & 152.00 & & 151.11 & \\
\hline 31 & $129.57^{*}$ & & 130.16 & \\
\hline 32 & 140.22 & $9.09 \mathrm{~s}$ & 143.62 & $9.28 \mathrm{~s}$ \\
\hline 33 & 157.35 & & 152.39 & \\
\hline 34 & 141.31 & & 154.86 & \\
\hline 35 & 121.37 & $8.50 \mathrm{~s}$ & 53.24 & $3.96 \mathrm{~s}$ \\
\hline $\mathrm{N} 1\left(\mathrm{NH}_{2}\right)$ & & & & 7.51 bs, 7.63 bs \\
\hline N4 & & $9.95 \mathrm{~s}$ & & $9.81 \mathrm{~s}$ \\
\hline N5 & & $8.77 d, 8.6$ & & $8.53 d, 8.1$ \\
\hline N6 & & $8.49 d, 6.6$ & & $7.99 \mathrm{~d}, 9.1$ \\
\hline
\end{tabular}

* Interchangeable 


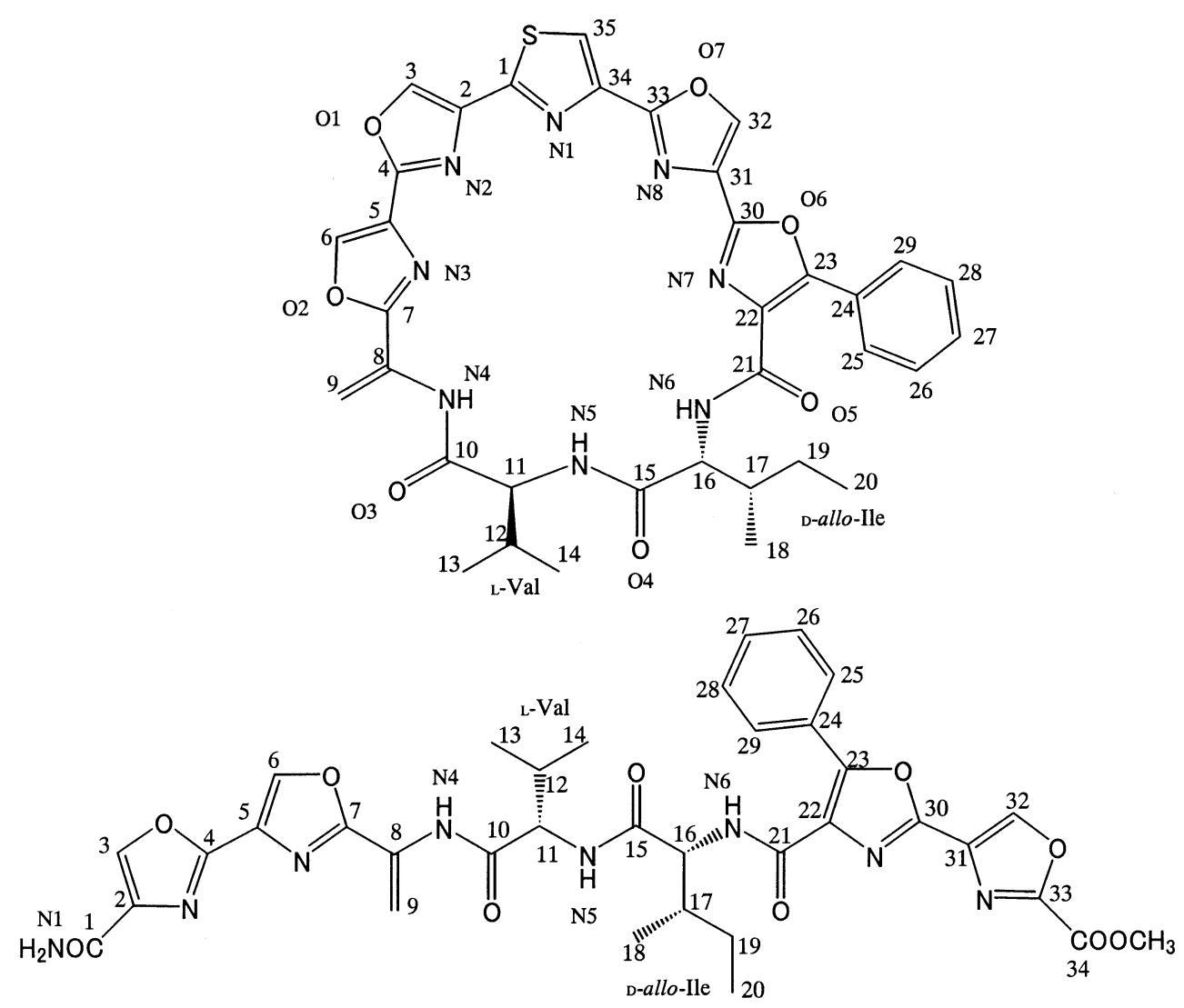

Fig. 1 Structures of $\mathbf{1}$ (upper) and $\mathbf{2}$ (lower).

The molecular formula of $\mathbf{1}$ was determined to be $\mathrm{C}_{35} \mathrm{H}_{32} \mathrm{~N}_{8} \mathrm{O}_{7} \mathrm{~S}$ from its HRFAB-MS data (Table 1). The peptide moiety was composed of a dehydroalanine fragment, valine and isoleucine as determined from the 2D NMR data, including COSY, TOCSY, HSQC and HMBC. The remaining structure, which was presumed to contain four consecutive oxazoles and a thiazole from an analysis of the chemical shift of ${ }^{1} \mathrm{H}$ and ${ }^{13} \mathrm{C}$ NMR and HMBC signals from aromatic protons to quaternary aromatic carbons, could not be fully determined by the NMR studies, because there was no correlation signal by HMBC between the oxazoles, as in the case of telomestatin [5]. Consequently, the structure of $\mathbf{1}$ was determined by an Xray crystallographic analysis. The applicable crystal was obtained by crystallization from dichloromethane/methanol $(1: 1)$. The crystal data and measurement conditions are summarized later [6], and the ORTEP drawing shown in Figure 2. The absolute configuration of $\mathbf{1}$ was determined from an X-ray anomalous dispersion of the $\mathrm{S}$ atom as shown in Figure 1.

The molecular formula of $\mathbf{2}$ was determined to be $\mathrm{C}_{35} \mathrm{H}_{36} \mathrm{~N}_{8} \mathrm{O}_{10}$ from the HRFAB-MS data (Table 1). The peptide moiety of $\mathbf{2}$ was determined by NMR studies, this

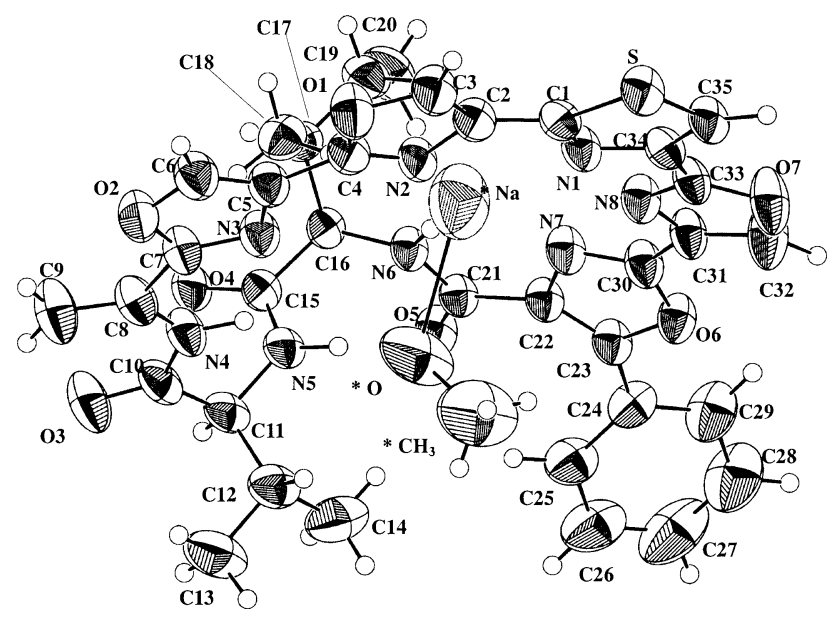

Fig. 2 Crystal structure of 1. ${ }^{*} \mathrm{NaOCH}_{3}$ in the crystal.

partial structure being the same as that of $\mathbf{1}$. The remaining partial structures of $\mathbf{2}$, involving four oxazole ring structures: an oxazole, a 5-phenyloxazole, an oxazole-2carboxylic acid methyl ester, and an oxazole-4-carboxylic acid amide, were determined from a detailed analysis of the NMR data. The respective connectivity of the oxazole and 
5-phenyloxazole was determined by the HMBC signals from $\mathrm{H} 9$ to $\mathrm{C} 7$ and from $\mathrm{N} 6-\mathrm{H}$ to $\mathrm{C} 22$. The connectivity of the oxazole-2-carboxylic acid methyl ester and oxazole-4carboxylic acid amide was not determined by the NMR studies, but instead by a fragment analysis of the LCMS/MS data, enabling the complete structure of 2 to be determined as shown in Figure 1. The absolute stereochemistry of $\mathbf{2}$ was determined by the Marfey's method [7] and a chiral HPLC analysis.

The cytotoxic activity of $\mathbf{1}$ was relatively strong, the $\mathrm{IC}_{50}$ value for A549 cells (human lung cancer) being $4.0 \times 10^{-8} \mathrm{M}$ and for Jurkat cells (human leukemia) being $4.6 \times 10^{-8} \mathrm{M}$ under our assay conditions [8], while 2 did not exhibit any inhibitory activity toward either cells even at $1 \times 10^{-6} \mathrm{M}$. The cyclic structure of 1 must have been essential for its strong antitumor activity. A further investigation of the antitumor potential of $\mathbf{1}$ is in progress.

Acknowledgments We thank Mr. Satoru Matsuda for measuring the LC-MS/MS data. This work was performed as part of the project entitled "Constructing the Genetic Resource Library of Unidentified Microbes Based on Genome Information" supported by New Energy and Industrial Technology Development Organization (NEDO).

\section{References}

1. Blunt JW, Copp BR, Munro MHG, Northcote PT, Prinsep MR. Marine natural products. Nat Prod Rep 21: 1-49 (2004)

2. Compound $\mathbf{1}$ was reported as a cytotoxic substance in a patent during the preparation of this manuscript. Romero $\mathrm{P}$, Malet L, Canedo LM, Cuevas C, Fernando RJ. New cytotoxic depsipeptides. WO 2005/000880 A2, January 6, 2005

3. The strain producing $\mathbf{1}$ and 2, YM3-251, has been identified as Thermoactinomyces sp. by taxonomic studies, including a 16S rDNA sequence analysis. The strain has been deposited in the NITE Patent Microorganisms Depositary (NPMD) in Japan as NITE P-2.
4. The B2 medium (1 liter) contained $5 \mathrm{~g}$ of peptone, $1 \mathrm{~g}$ of yeast extract, $0.1 \mathrm{~g}$ of iron (III) citrate $n$-hydrate, $750 \mathrm{ml}$ of filtered natural sea water, and $250 \mathrm{ml}$ of distilled water $(\mathrm{pH}$ 7.6, before sterilization).

5. Shin-ya K, Wierzba K, Matsuo K, Ohtani T, Yamada Y, Furihata K, Hayakawa Y, Seto H. Telomestatin, a novel telomerase inhibitor from Streptomyces anulatus. J Am Chem Soc 123: 1262-1263 (2001)

6. The crystal used for the X-ray crystallographic analysis contained sodium methoxide. Crystal data for $\mathbf{1}$ : $\mathrm{C}_{36} \mathrm{H}_{35} \mathrm{~N}_{8} \mathrm{NaO}_{8} \mathrm{~S}$, colorless cube, $M_{\mathrm{r}}=762.768$, triclinic $P \overline{1}$, $a=11.7380(8) \AA, \quad b=12.9590(11) \AA, \quad c=13.1900(10) \AA$, $\alpha=89.999(6)^{\circ}, \quad \beta=90.062(7)^{\circ}, \quad \gamma=110.351(3)^{\circ}, \quad V=$ 1881.1(2) $\AA^{3}, Z=2, \rho_{\text {calcd }}=1.322 \mathrm{mg} \mathrm{m}^{-3}, \mu=0.158 \mathrm{~mm}^{-1}$, $T=298 \mathrm{~K}, 9879$ measured reflections, 9879 independent reflections, 973 parameters, $\mathrm{GOF}=1.005, \quad R 1(w R 2)=$ $0.0495(0.1367)$. The measurements were carried out on Mac Science (Bruker Nonius) dip image plate diffractometer using graphite-monochromated $\mathrm{MoK}_{\alpha}$ radiation $(\lambda=071073 \AA)$. The crystal structure was solved by the direct method with SIR-97. Refinement was performed by a full matrix least squares refinement on $\mathrm{F}^{2}$ with SHELXL-97. CCDC 262340 contains the supplementary crystallographic data for this paper. These data can be obtained free of charge from The Cambridge Crystallographic Data Centre via www.ccdc.cam.ac.uk/data_request/cif.

7. Marfey P. Determination of D-amino acids. II. Use of a bifunctional reagent, 1,5-difluoro-2,4-dinitrobenzene. Carlsberg Res Commun 49: 591-596, 1984

8. A549 cells were cultured in a DMEM medium containing $10 \%$ fetal bovine serum. The cells were seeded in a $96-$ well microplate $(4,000$ cells $/ 200 \mathrm{ml} /$ well $)$ and then cultured in a $\mathrm{CO}_{2}$ incubator $\left(5 \% \mathrm{CO}_{2}\right.$ - air, $\left.37^{\circ} \mathrm{C}\right)$ for 14 hours. Serially diluted samples were added to each well, and the cells were cultured for a further 48 hours. The cell number was counted by the Alamar Blue ${ }^{\mathrm{TM}}$ method, and the $\mathrm{IC}_{50}$ value was determined from three independent experiments. Jurkat cells were cultured in an RPMI 1640 medium containing 10\% fetal bovine serum. The $\mathrm{IC}_{50}$ value for the Jurkat cells was determined by the same procedure as that used for the A549 cells. The $\mathrm{IC}_{50}$ value of staurosporine for the A549 cells was $3.5 \times 10^{-8} \mathrm{M}$, and for the Jurkat cells was $1.5 \times 10^{-8} \mathrm{M}$. 